\title{
Analysis of Students' Digital Citizenship Practices on Distance Learning Activities During Pandemic Covid-19
}

\author{
Devita Puspa Sari ${ }^{1 *}$, Sapriya Sapriya ${ }^{2}$, Susan Fitriasari $^{3}$ \\ ${ }^{1,2,3}$ Civic Education Department, Universitas Pendidikan Indonesia, Bandung, Indonesia \\ *Corresponding author. Email: puspadevita14@upi.edu
}

\begin{abstract}
This paper describes how students practice digital citizenship in distance learning conditions during the covid-19 pandemic. The position of technology changed the foundation of education that was initially done face-to-face switching to online learning activities. This situation certainly requires a special understanding of the competence of digital citizenship so that students as technology users can be wise and responsible. In remote online learning activities, several elements need to be studied more deeply in the practice of digital citizenship of students, such as the ability to use technology media, identify secure websites, protect personal privacy, and understand the rule of law in the use of digital technology. The purpose of this study is to analyze how the practice of digital citizenship of students is carried out, whether it is following the expected elements or not. This study uses a qualitative method with a descriptive approach, the research participants were taken from nine informants consisting of grade VII, VIII, and IX students at Permata Bunda Islamic School. Research data is obtained from observation processes, in-depth interviews, and document analysis. The results of this study show that students have been able to use digital media well seen from their ability to apply e-learning media and be able to maintain their privacy in digital media. But students do not have a deep understanding of the rule of law in the use of digital media so students still often make mistakes such as taking data without listing sources, spreading the word without reviewing the truth, and unknowingly doing bullying through social media.
\end{abstract}

Keywords: Digital Citizenship, Distance Learning, Learning During Pandemic

\section{INTRODUCTION}

The emergence of the Covid-19 pandemic changed the climate of most dimensions of life, ranging from health, socio-cultural, economic, and educational fields. This condition certainly has a big impact on the adaptation of a new culture built to prevent the spread of the Covid-19 virus. Especially in the world of education, the ministry of education was forced to change the learning process from a face-to-face system to online learning which certainly needs an extra process to make this learning system change effectively used.

With this system teachers are designed to be able to provide instructional activities to students in a new format, using e-learning media that certainly requires good digital understanding for its implementation to be maximized. Not only teachers, but students also need to get used to being able to apply various digital media such as Google Classroom, Google Meet, Zoom Meeting, Quizzes, and e-learning media specially designed by the school. This transition will not go well if each element does not collaborate to the fullest. The changing conditions of this learning process will be felt quickly because students have been practicing to work on projects at different speeds according to the development of generation $\mathrm{Z}$ that is so closely related to the digital world, students will get used to utilizing the school district's digital platform even though this seems new to some elements [1].

School districts have made digital learning a necessity rather than an option; however, in a survey of more than $2,000 \mathrm{~K}-12$ teachers, $60 \%$ of educators surveyed described passive use of technology in their schools with activities such as watching videos and reading websites. About $10 \%$ of teachers have been able to use high-level technology in their online classrooms, $60 \%$ need selfdevelopment to be able to professionally integrate technology, and $30 \%$ of teachers surveyed stated that the school is capable of providing one digital device per student. In this increasingly demanding digital world, young people and digital natives are trying to maximize engagement, while teachers are struggling to develop student learning processes and outcomes with minimal knowledge related to the effective use of digital tools [2]. 
Digital tools can give teachers the teaching and learning resources needed to personalize instruction for each student, deepen concept understanding, motivate student engagement, and make real-world connections [3]. The practice of digital citizenship has become the center of attention in the world of education lately, this is reviewed from the conditions of learning conducted remotely by utilizing digital media as a guide to the learning process to keep going. This condition is the result of the Covid-19 pandemic that changed the pattern of life in various fields such as education, health, economy, and social culture almost all over the world. The Central Bureau of Statistics states that $91.3 \%$ or 1.5 billion students worldwide are unable to study in schools to reduce the intensity of the spread of the Covid-19 virus. To follow up on this condition, the Indonesian government issued Circular Letter No. 15 of 2020 on Guidelines for the Implementation of Learning from Home during the Covid-19 emergency period which will essentially be implemented with a distance learning system by utilizing digital media to keep the learning process carried out properly.

The minister of education explained that the implementation of distance learning should be able to give meaning to every learning experience, without having to be a burden for students in achieving learning competencies. Meaningful learning requires teachers, students, and parents to understand each other's conditions so that the process of transferring knowledge can run optimally, interaction and good communication must be intensively established as a form of cooperation to overcome access gaps in distance learning.

With the emergence of various online learning media applications, and every student is required to be able to apply various media learning applications ideally. An important point to note is how the impact is presented when all students' learning activities go from online activities in digital media and the use of gadgets or laptops not only for learning but also for other things such as the intensity of students surfing social media, gaming applications, and other entertainment media. In practice, there will be a lot of time students spend in the digital world and this certainly reaps an impact, both positive and negative. The emergence of various online learning with media applications, and every student is required to be able to apply various media learning applications ideally.

An important point to note is how the impact is presented when all students' learning activities go from online activities in digital media and the use of gadgets or laptops not only for learning but also for other things such as the intensity of students surfing social media, gaming applications, and other entertainment media. In practice, there will be a lot of time students spend in the digital world and this certainly reaps an impact, both positive and negative.

On this occasion, researchers will focus on reviewing students' digital citizenship practices on elements of digital communication, digital literacy, and digital ethics. As active users of digital media students need to be observed in depth how digital communication practices, digital literacy, and digital ethics when using digital technology media in distance learning activities during the Covid-19 pandemic. This is done as a form of anticipation of negative impacts that will harm it both in terms of digital media abuse, piracy, cyberbullying, fraud, and so on. Then the researchers want to analyze how students' digital citizenship practices directly, in the hope of understanding further the condition of students with the digital world and find solutions to overcome the problems.

\section{METHODS}

Overall, in the practice of student digital citizenship, some elements such as digital communication, digital literacy, and digital ethics have been able to be applied properly and responsibly. But regardless, there are still some students who still need special assistance in using and utilizing digital media, so that they are more targeted to their activities, and avoid adverse effects such as pornography, fraud, plagiarism, and fake news. The role of school and family mentoring is an important aspect in educating students to be able to play the role of wise digital citizens. Because the purpose of this study is to know the implementation of digital citizen practices in students, the researchers chose the main informant, namely students as the main actors implementing the digital-based learning process today. The subject or participants in this researched are;

Table 1. Participants Researched

\begin{tabular}{|c|l|c|}
\hline No & \multicolumn{1}{|c|}{ Participan } & Quantity \\
\hline 1 & Theacher Civic Education & 3 \\
\hline 2 & $\begin{array}{l}\text { Student in Civic Class } \\
\text { Grade VII }\end{array}$ & 2 \\
\hline 3 & $\begin{array}{l}\text { Student in Civic Class } \\
\text { Grade VIII }\end{array}$ \\
\hline 4 & $\begin{array}{l}\text { Student in Civic Class } \\
\text { Grade IX }\end{array}$ & 2 \\
\hline & \multicolumn{1}{|c|}{ Amount } & 9 \\
\hline
\end{tabular}

Data analysis techniques that researchers will use are the implementation of direct observation, interviews with informants using a special and natural approach so that informants can convey accurate and comprehensive information, and conducting document analysis as a supporting component of the completeness of research data.

Figure 1. Data Analysis

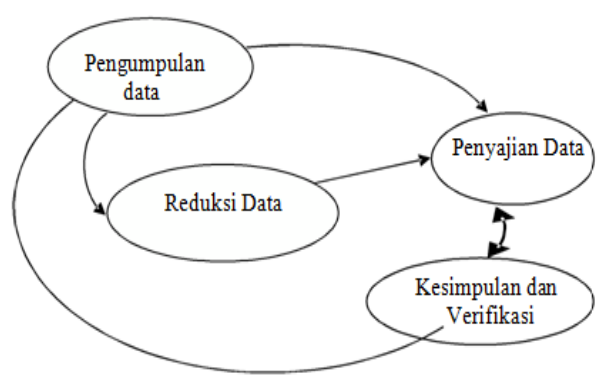


The data collection process uses non-participatory observations. The reason is that because researchers are not directly involved and only as independent observers in the activities carried out, researchers only play a role in observing, recording, and making conclusions about students' digital citizenship practices on distance learning activities during the covid-19 pandemic.

\section{RESULT AND DISCUSSION}

This section will present findings and data analysis on students' digital citizenship practices based on elements of digital communication, digital proficiency, and digital ethics in distance learning activities during the Covid-19 pandemic. The data excerpts below are taken from a review of the latest news information, live observations, and interviews with three subject teachers, and six students as key informants.

\subsection{Digital Citizenship Practice}

Digital citizenship is defined as one's behavior in using digital technology [4]. Digital citizens are those who demonstrate appropriate and responsible norms of behavior regarding the use of digital technology [5]. The International Society for Technology in Education [6] lists digital citizenship as an important aspect that students should be taught. [7] states that digital citizenship is character education in the digital age, while [8] defines digital citizenship as a practice of respect and tolerance towards others. [9] concludes that digital citizenship requires high school students to learn citizenship directly through the software, games, and other digital media applications.

Digital citizenship is multidimensional, covering the science, attitudes, and behaviors of digital citizenship. The focus of digital citizenship education lies in the ability to qualify for a healthy digital identity, trust, protection, and use [10] Based on the results of his research, [11] directs that digital citizenship education should begin as early as possible, noble from preschool to secondary level, especially training that gives students an understanding of the creation of a digital footprint.

\subsection{Digital Citizenship Standars Concept}

The digital age beckons us to usher in a new era of character education aimed directly at overcoming the opportunities and challenges of living a digital lifestyle [7]. Teachers and students in this regard should be able to use digital devices and tools to be able to create $21 \mathrm{st}$ century digital learning experiences in the classroom and at home [12]. Based on research conducted by [13] offsetting the development of 21 st-century skills in the world of education requires a curriculum that can cover six important elements for the development of digital citizenship, namely digital literacy, innovative thinking, critical thinking, digital citizenship, self-learning, and computer-supported collaboration.

Some instructional guidelines for digital citizenship will be of great benefit to teachers and schools consistently ideally use the same type of digital devices, allowing technology support staff to load applications, maintain sites, train teachers and students to be able to solve digital learning problems as needed [14]. Digital learning over the social Web creates the potential for simultaneous learning and recreational activities, both teachers and students must adapt their pedagogical practices to deal with the collapse of the spatial and temporal boundaries of learning and recreation [15].

In addition, triangulation communication between students, schools, and homes, as well as consistent technological rules are very important factors for students to be able to be responsible in the use of technology [16]. Cristol and Gimbert discover a strong link between internet teacher self-efficacy and digital citizenship [17].

\subsection{Distance Learning}

Reviewing the condition of the new era of education during the Covid-19 pandemic, there is certainly a new learning implementation design developed, one of which is the concept of distance learning. This concept was applied more than 250 years ago, the process of distance learning learners at that time began with the exchange of lesson materials through traditional letters between teaching institutions and learners, known as correspondence education [18]. Distance learning today is defined as a learning process that utilizes technical media (audio, video, text) to deliver subject matter content with a gradual system through top-down information channels in remote classrooms that can limit ideological outcomes [19]. Distance learning in countries such as Australia and Finland is generally applied at all levels of education. For example, Australia uses four models of distance learning, namely correspondence, multi-module, del e-learning, and flexible teaching [20] the most widely used is the flexible teaching model because it allows its implementation online and offline using CD publications and the global Internet, this is widely known as blended learning. This pattern has been widely applied in the majority of Australian universities and various secondary schools.

Distance learning also supports the development of traditional training programs to enhance knowledge, skills, and learning implementation in accordance with today's technological life cycle verified for distance learning applications [21]. The great potential of distance learning is as a solution to increase the effectiveness of teaching, reduce time and cost compared to traditional teaching, and become a competitive tool in the education market [22].

Distance Learning has two equally important orientations so that the implementation can run conditionally, it is necessary to note how the readiness of teachers and the readiness of learners in carrying it out. Distance learning in other opinions is defined as a planned learning experience, which is made to provide interesting learning for students whose location is far away and even able to reach students around the world 
by establishing good communication with students. The basic development of distance learning can be qualified in four stages, namely correspondence course stage, multimedia communication stage both print, radio, and television, then synchronous learning stage, and flexible learning stage where internet starts to enter.

Distance learning will be very closely related to information technology because distance learning programs require help from internet networks, computers, and computerized systems (laptop, smartphone, tablet, etc.) as a means of supporting the learning process. In this case Khlaif states that most teachers consider that tablets are beneficial for classroom activities, collaboration, and debate among peers [23]. This situation is also known as e-learning which is a learning process that utilizes electronic media and internet networks for the main media of learning so that access to education can take place anywhere and anytime [24].

From the initial data collection process that has been done, researchers grouped the findings as follows,

1. Digital Communion, as a large number of students are considered to have been able to use good and polite communication language through digital communication media WhatsApp, Zoom Meeting, and other online learning platforms, but there are some among students who still often make mistakes in word writing when communicating with teachers through WhatsApp media. On the other hand, students' level of digital communication skills is seen from their social media, how the language is used, the posts shared, and the fact that there are still some students who are not wise in using words when making posts on their social media.

2. Digital Literacy, In terms of digital literacy, students are judged to have met the criteria of being able to use digital learning media well, understanding digital media features such as study room applications, social media, and email applications. In other cases, learners still need to be redirected on how to filter information in digital media, the ability to distinguish valid information and hoaxes. To make students wiser when conveying updated information to their friends.

3. Digital Ethics, Digital ethics students need to be redirected, because often in learning activities via zoom meetings, students disable video features that are not directly less appreciative of teachers in online classrooms. But on the other hand, students have been able to take responsibility in using the media, judging by the way they communicate well and politely so as not to offend the interlocutor. Students have also been able to do class attendance, do assignments and collect them according to the time set by the teacher on the online learning platform although not all students map realize it, this has become the starting point for students to be able to ethically use digital media in the context of class attendance and assignment collection

In the practice of digital citizenship students certainly some provisions of which have been able to be fulfilled properly and responsibly. But despite that, there are still some students who still need special assistance in using and utilizing digital media. Hollandsworth assume that teachers' awareness of digital citizenship has increased more than there is [25]. The role of schools and families is such an important aspect in educating students to be able to play an ideal role as digital citizens.

Table 2. Element of Digital Citizenship

\begin{tabular}{|c|c|c|c|c|}
\hline \multirow{2}{*}{ No } & \multirow{2}{*}{ Subject } & \multicolumn{3}{|c|}{ Element of Digital Citizenship } \\
\hline & & $\begin{array}{c}\text { Digital } \\
\text { Communion }\end{array}$ & $\begin{array}{c}\text { Digital } \\
\text { Literacy }\end{array}$ & Digital Ethics \\
\hline 1 & $\begin{array}{c}\text { Teacher } \\
\text { A }\end{array}$ & $\begin{array}{l}\text { Students } \\
\text { have been } \\
\text { able to use } \\
\text { good and } \\
\text { polite } \\
\text { communicati } \\
\text { on language } \\
\text { through } \\
\text { Whatsapp } \\
\text { digital } \\
\text { communicati } \\
\text { on media, } \\
\text { Zoom } \\
\text { Meeting, and } \\
\text { other online } \\
\text { learning } \\
\text { platforms }\end{array}$ & $\begin{array}{l}\text { In terms of } \\
\text { digital literacy, } \\
\text { students are } \\
\text { considered to } \\
\text { have met the } \\
\text { criteria of being } \\
\text { able to use } \\
\text { digital learning } \\
\text { media well, } \\
\text { understand } \\
\text { digital media } \\
\text { features such as } \\
\text { study room } \\
\text { applications, } \\
\text { social media, } \\
\text { and email } \\
\text { applications }\end{array}$ & $\begin{array}{l}\text { Ethically } \\
\text { digital } \\
\text { students need } \\
\text { to be re- } \\
\text { directed, } \\
\text { because often } \\
\text { in learning } \\
\text { activities via } \\
\text { zoom meeting, } \\
\text { students } \\
\text { disable video } \\
\text { features that } \\
\text { are not } \\
\text { directly less } \\
\text { appreciative of } \\
\text { teachers in } \\
\text { online } \\
\text { classrooms }\end{array}$ \\
\hline 2 & $\begin{array}{c}\text { Teacher } \\
\text { B }\end{array}$ & $\begin{array}{l}\text { Students are } \\
\text { able to } \\
\text { establish } \\
\text { good } \\
\text { cooperation } \\
\text { with their } \\
\text { study group } \\
\text { when } \\
\text { completing } \\
\text { group tasks } \\
\text { online }\end{array}$ & $\begin{array}{l}\text { Students } \\
\text { already } \\
\text { understand the } \\
\text { features of } \\
\text { learning, and } \\
\text { know how to } \\
\text { present learning } \\
\text { video } \\
\text { assignments } \\
\text { during the } \\
\text { online learning } \\
\text { process }\end{array}$ & $\begin{array}{l}\text { From the } \\
\text { observations } \\
\text { made, students } \\
\text { have been able } \\
\text { to take } \\
\text { responsibility } \\
\text { in using the } \\
\text { media, judging } \\
\text { by the way } \\
\text { they } \\
\text { communicate } \\
\text { well and } \\
\text { politely so as } \\
\text { not to offend } \\
\text { their } \\
\text { interlocutor }\end{array}$ \\
\hline 3 & $\begin{array}{c}\text { Teacher } \\
\text { C }\end{array}$ & $\begin{array}{l}\text { Students } \\
\text { perform } \\
\text { prayers, } \\
\text { recite Verses } \\
\text { of the Quran } \\
\text { in the } \\
\text { morning, and } \\
\text { fast }\end{array}$ & $\begin{array}{l}\text { In this case } \\
\text { learners need to } \\
\text { be redirected } \\
\text { how to filter } \\
\text { information in } \\
\text { digital media, } \\
\text { the ability to } \\
\text { distinguish } \\
\text { valid } \\
\text { information and } \\
\text { hoaxes. To } \\
\text { make students } \\
\text { wiser when } \\
\text { sharing } \\
\text { information } \\
\text { with friends }\end{array}$ & $\begin{array}{l}\text { Students are } \\
\text { sometimes still } \\
\text { not good at } \\
\text { word writing } \\
\text { when } \\
\text { communicatin } \\
\text { g with } \\
\text { teachers via } \\
\text { Whatsapp } \\
\text { media }\end{array}$ \\
\hline
\end{tabular}




\begin{tabular}{|c|c|c|c|c|}
\hline 4 & $\begin{array}{c}\text { Student } \\
\text { Grade VII } \\
\text { A }\end{array}$ & $\begin{array}{l}\text { Students are } \\
\text { able to } \\
\text { establish } \\
\text { relationships } \\
\text { with their } \\
\text { friends } \\
\text { digitally } \\
\text { through } \\
\text { social media }\end{array}$ & $\begin{array}{l}\text { The student } \\
\text { has been able } \\
\text { to use digital } \\
\text { learning } \\
\text { media, able } \\
\text { to solve } \\
\text { problems } \\
\text { encountered } \\
\text { while using } \\
\text { media }\end{array}$ & $\begin{array}{l}\text { The student has } \\
\text { been wise in } \\
\text { using digital } \\
\text { media }\end{array}$ \\
\hline 5 & $\begin{array}{c}\text { Student } \\
\text { Grade VII } \\
\text { B }\end{array}$ & $\begin{array}{l}\text { The student } \\
\text { has been } \\
\text { good at } \\
\text { establishing } \\
\text { communicati } \\
\text { on with } \\
\text { teachers } \\
\text { through } \\
\text { whatsapp } \\
\text { communicati } \\
\text { on media }\end{array}$ & $\begin{array}{l}\text { The student } \\
\text { still needs } \\
\text { special } \\
\text { direction } \\
\text { from parents } \\
\text { in applying } \\
\text { digital } \\
\text { learning } \\
\text { media }\end{array}$ & $\begin{array}{l}\text { The student is } \\
\text { good at } \\
\text { connecting with } \\
\text { the community, } \\
\text { has good ethics in } \\
\text { interacting }\end{array}$ \\
\hline 6 & $\begin{array}{c}\text { Student } \\
\text { Grade VIII } \\
\text { A }\end{array}$ & $\begin{array}{l}\text { The student } \\
\text { continues to } \\
\text { do social } \\
\text { activities, by } \\
\text { holding } \\
\text { fundraisers } \\
\text { through } \\
\text { digital media }\end{array}$ & $\begin{array}{l}\text { Students } \\
\text { have been } \\
\text { able to } \\
\text { understand } \\
\text { the features, } \\
\text { guides, and } \\
\text { how to } \\
\text { maintain } \\
\text { privacy in } \\
\text { digital media }\end{array}$ & $\begin{array}{l}\text { The student has } \\
\text { been able to } \\
\text { manage himself } \\
\text { to care about the } \\
\text { surrounding } \\
\text { environment }\end{array}$ \\
\hline 7 & $\begin{array}{c}\text { Student } \\
\text { Grade VIII } \\
\text { B }\end{array}$ & $\begin{array}{l}\text { The student } \\
\text { is less active } \\
\text { in group } \\
\text { assignments, } \\
\text { and activities } \\
\text { in online } \\
\text { classes }\end{array}$ & $\begin{array}{l}\text { Students } \\
\text { have } \\
\text { sophisticated } \\
\text { mobile } \\
\text { phones, this } \\
\text { certainly } \\
\text { indicates that } \\
\text { they have } \\
\text { been able to } \\
\text { understand } \\
\text { more } \\
\text { complex } \\
\text { digital media } \\
\text { applications }\end{array}$ & $\begin{array}{l}\text { The student needs } \\
\text { assistance in } \\
\text { order to be able to } \\
\text { be wise in } \\
\text { communicating, } \\
\text { especially ketinya } \\
\text { disseminating } \\
\text { information }\end{array}$ \\
\hline 8 & $\begin{array}{c}\text { Student } \\
\text { Grade IX } \\
\text { A }\end{array}$ & $\begin{array}{l}\text { The student } \\
\text { remains } \\
\text { active in } \\
\text { participating } \\
\text { in several } \\
\text { extracurricul } \\
\text { ar activities } \\
\text { conducted } \\
\text { through } \\
\text { online } \\
\text { communicati } \\
\text { on media }\end{array}$ & $\begin{array}{l}\text { This student } \\
\text { has an } \\
\text { extensive } \\
\text { network of } \\
\text { friendships } \\
\text { on social } \\
\text { media, this is } \\
\text { a picture that } \\
\text { he has been } \\
\text { able to } \\
\text { understand } \\
\text { the use of } \\
\text { media well }\end{array}$ & $\begin{array}{l}\text { The student is } \\
\text { always kind } \\
\text { during class or } \\
\text { when } \\
\text { communicating } \\
\text { personally }\end{array}$ \\
\hline 9 & $\begin{array}{c}\text { Student } \\
\text { Grade IX } \\
\text { B }\end{array}$ & $\begin{array}{l}\text { The student } \\
\text { is always } \\
\text { active in } \\
\text { online classes } \\
\text { and } \\
\text { appreciates } \\
\text { friends who } \\
\text { are being } \\
\text { percentageed } \\
\text { through } \\
\text { zoom media }\end{array}$ & $\begin{array}{l}\text { Students still } \\
\text { need teacher } \\
\text { direction in } \\
\text { applying } \\
\text { digital } \\
\text { learning } \\
\text { media during } \\
\text { the online } \\
\text { learning } \\
\text { process }\end{array}$ & $\begin{array}{l}\text { The student } \\
\text { always tries to } \\
\text { answer the } \\
\text { teacher's } \\
\text { questions in the } \\
\text { online classroom }\end{array}$ \\
\hline
\end{tabular}

Based on the following table view, teachers A, B, and $\mathrm{C}$ can be seen thinking that students have been able to use good and polite communication language through digital communication media Whatsapp, Zoom Meeting, and other online learning platforms, and students have been able to establish good cooperation with their study group when completing group tasks online. Although ethically digital, students need to be redirected, because often in learning activities via zoom meetings, students disable the video feature, which indirectly lacks respect for teachers in online classes. The good news is that students already understand the features of learning, and the know-how to present learning video assignments during the online learning process. From the findings in students, in general, students have been good at establishing communication with teachers through WhatsApp communication media, in which case students need to be redirected on how to filter information in digital media, the ability to distinguish valid information and hoaxes. To make students wiser when sharing information with friends. Broadly speaking, students have been able to implement themselves as digital citizens even though the education process is based on distance learning, and from the observations made, students have been able to be responsible in using the media, judging by the way they communicate well and politely so as not to offend their interlocutors, and students have been able to use digital learning media, able to solve problems encountered when using the media.

This is a form of student success indicator as good digital citizenship. With the knowledge of the character of learners can understand how to distinguish good and bad things and able to project themselves to have good character, then with the ability to feel learners through conscience and empathy can do good that comes from sincerity of heart, then this is ultimately transferred into the aspect of action so that students responsively with knowledge and feelings can practice good character in be for real actions in daily life following the expected values.

\section{CONCLUSION}

This research illustrates that good digital citizenship certainly involves many elements that will allow students to be able to play an active role digitally, develop with their creativity, show students how they can connect using only a digital network, and this will train students to be able to empathize with each other, creating harmonious relationships through digital tools. While digital citizenship is bad, on the other hand, it will be so closely related to the issue of cyberbullying, irresponsible use of social media, the spread of hoax news for the lack of general knowledge on how to use the Internet properly and safely in line with the regulations of the Undang-Undang Number 11 of 2008 on Information and Electronic Transactions. 


\section{ACKNOWLEDGMENTS}

Thanks to LPDP Ministry of Finance of the Republik Indonesia for funding this research. Thanks to Permata Bunda Islamic School which has given permission to carry out this research, and thanks to the mentor Prof. Sapriya, M.Ed and Dr. Susan Fitriasari, M.Pd. for guidance and advise during this research.

\section{REFERENCES}

[1] S . Schwartz, Teachers Scramble to Make Remote Learning Work, Education Week, 2020

[2] Price Waterhouse Coopers, Technology In US Schools: Are We Preparing Our Kids For The Jobs Of Tomorrow?, 2018

[3] Dahlberg, G. and P. Moss, Ethics and Politics in Early Childhood Education, Routledge Falmer, London, 2015

[4] Florence Martin; Tuba Gezer; Chuang Wang, Educators' Perceptions of Student Digital Citizenship Practice. Computers In the Schools, 2019

[5] M. Ribble, Digital citizenship in schools. International Society for Technology in Education. Eugene, OR: International Society for Technology in Education, 2014

[6] International Society for Technology in Education (ISTE), "Standards for Students", 2019 https://www.iste.org/standards/for-students

[7] J. Ohler, Digital Citizenship Means Character Education for The Digital Age. Kappa Delta Pi Record, 2011, 48(1), 25-27. https://doi.org/10.1080/00228958.2011.10516720

[8] L. M. Jones \& K. J. Mitchell, Defining And Measuring Youth Digital Citizenship. New Media and Society. 2015, 18(9), 2063-2079 https://doi.org/10.1177/1461444815577797

[9] B. Gleason \& S. Von Gillern, Digital Citizenship with Social-Media: Participatory Practices Of Teaching And Learning In Secondary Education, Journal of Educational Technology \& Society, 2018

[10] M. Kim, \& D. Choi, Development Of Youth Digital Citizenship Scale And Implication For Educational Setting, Journal of Educational Technology \& Society, 2018

[11] R., Donovan, J., Hollandsworth, \& M. Welch, Digital Citizenship: You Can't Go Home Again. TechTrends. 2017, 61(6), 524-530. https://doi.org/10.1007/s11528-017-0190-4
[12] Ashlee Hover and Teresa Wise, Exploring ways to create 21 st century digital learning experiences, International Journal of Primary, Elementary and Early Years Education, 2020 https://doi.org/10.1080/03004279.2020.1826993

[13] K. Van de Oudeweetering \& J. Voogt, Teachers' Conceptualization and Enactment Of TwentyFirst Century Competences: Exploring Dimensions For New Curricula, The Corriculum Journal, 2018, $29 \quad$ (1), 116133.https://doi.org/10.1080/09585176.2017.1369 136

[14] U.S. Department of Education, Building Technology Infrastructure for Learning, 2017 https://tech.ed.gov/infrastructure/

[15] D. McGillivraya , G. McPhersona, J. Jonesa \& A. McCandlisha, Young people, digital media making and critical digital citizenship, A School of Media, Culture and Society, University of the West of Scotland (UWS), High Street, Paisley, Scotland PA12BE, UK, 2014

[16] Mark, L. K., \& Nguyen, T. T, an invitation to Internet safety and ethics: School and family collaboration, Journal of Invitational Theory and Practice, 2017, 23, 62-75 Retrieved from https://eric.ed.gov/?id=EJ1184559

[17] Cristol, D., \& Gimbert, B. G., Teachers as digital citizens: Factors influencing teachers' levels of digital citizenship, In D. Parsons, R. Power, A. Palalas, H. Hambrock, \& K. MacCallum (Eds.), Proceedings of 17th World Conference on Mobile and Contextual Learning, Chicago, IL: Concordia University Chicago, 2018, (pp. 1-7).

[18] S. Hubackhova, History and Perspectives of Elearning. Procedia - Social and Behavioral Sciences, 2015

[19] Glassman, M., DeMOOCing society: Convivial tools to systems and back again in the information age. Educational Philosophy and Theory, 2019, 51(14), 1413-1422.

[20] Aleksandra Kruszewska; Stanislawa Nazaruk,; Karolina Szewczyk, Polish Teachers Of Early Education In The Face Of Distance Learning During The COVID-19 Pandemic-The Difficulties Experienced And Suggestions For The Future, Education. 2020, 1-12

[21] Gurcan, F., \& Cagiltay, N. E., Research trends on pembelajaran jarak jauh: a text mining-based literature review from 2008 to 2018, Interactive Learning Environments, 2020, 1-22

[22] Rahim, A. S., Online Education During Covid-19 Pandemic; An Experience of Riphah International 
University Faculty of Health and Medical Sciences, Pakistan Armed Forces Medical Journal, Special Issue 2020, 2, 70 (2): 506-512.

[23] Khlaif, Z, Teachers' perceptions of factors affecting their adoption and acceptance of mobile technology in K-12 settings, Computers in the Schools, 2018, 35(1), 49-67 https://doi.org/10. $\underline{1080 / 07380569.2018 .1428001}$

[24] Y. Xu, L. H. Li, , S. Zha Yu, W. He, and C. Hong, Influence of Mobile Devices' Scalability on Individual Perceived Learning, Behaviour and Information Technology 3001, 2020

[25] Hollandsworth, R., Donovan, J., \& Welch, M., Digital citizenship: You can't go home again, TechTrends, 2017, 61(6), 524-530 https://doi.org/10.1007/s11528-017-0190-4 